\section{GMO roundup}

Public antipathy seems set to spread from genetically modified crops to other areas of biological technology. Writing in the UK newspaper, The Daily Telegraph, Matt Ridley raises the specter of "atomic-GM," a form of genetic modification "so scary that the dangers posed by ordinary GM pale by comparison." Drawing a sharp contrast with current methods of "precise-GM" that work by inserting single genes into plant cells, Ridley describes how atomic-GM exposes seeds to heavy doses of gamma rays from a nuclear source, resulting in severe, widespread, and random genetic damage. The method renders most seed useless, but occasionally alterations occur that lead to more productive strains. There is no way to know which of the genes have been mutated or how. Scandalously, says Ridley, the crop goes straight into the field with no safety testing.

The article also points out that, oddly, the environmental movement has campaigned in favor of those derived by atomic-GM. Ridley reveals that crops produced in this way have been around so long-since the 1950s, indeed-that they are usually called "conventional" crops, those used by all farmers, including organic ones.

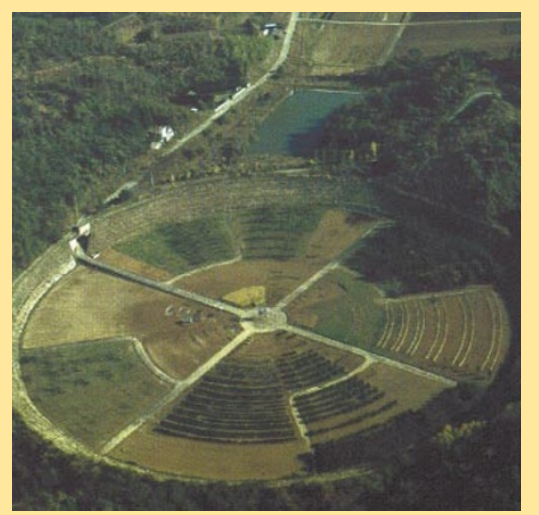

Part of the Atomic-GM facility at Institute of Radiation Breeding (Ibaraki, Japan). The gamma field has a radius of $100 \mathrm{~m}$ and a $88.8 \mathrm{TBq}$ Cobalt- 60 source at the center.

Business and Regulatory news briefs written by Emma Dorey, Jeff Fox, Vicki Glaser, Julie Grisham, John Hodgson, Sabine Louët, Asako Saegusa, and Keely Savoie.

\section{IBM joins SNP Consortium}

IBM has become the second information technology company (the other being Motorola) to join the SNP Consortium, a two-year, $\$ 50$ million initiative being led by 10 pharmaceutical companies and the Wellcome Trust to identify and analyze at least 300,000 single nucleotide polymorphisms (SNPs) in the human genome. Each member contributes $\$ 3$ million toward the research effort, and each has a seat on the consortium board (Nat. Biotechnol., 17, 526). IBM consolidated its disparate biological resources into an internal life sciences industry organization in 1999, and in December announced a $\$ 100$ million initiative to build the Blue Gene supercomputer for modeling protein folding (Nat. Biotechnol. 18, 8, 2000). Understanding how particular genes, groups of genes, or genomic variants affect gene and protein expression and integrating that information across large numbers of individuals is "an information technology challenge, if not more than a biology challenge," says Arthur Holden, chairman and CEO of the SNP Consortium. IBM was motivated to join the consortium by its desire "to do the proof of concept in real customer situations," according to an IBM spokesperson.

$V G$

\section{British Biotech: Still waiting}

British Biotech (Oxford, UK) has suffered yet another disappointment related to its anticancer drug marimastat (Nat. Biotechnol., 17, 409, 1999). The company's most recent phase III clinical trial looked at the effect of the matrix metalloproteinase inhibitor on patients with advanced pancreatic cancer and found no significant improvement in survival rates compared with placebo. When tested in combination with nucleoside analog gemcitabine, no significant benefits were attributable to marimastat. British Biotech shares fell more than $40 \%$ to $\$ 415 / 16$ following news of the trial. Despite the setback, the company and its partner, Schering-Plough (Madison, $\mathrm{NJ}$ ), say they will go forward with development of the drug. Results from four additional ongoing trials are expected sometime in 2000: two studies on small-cell lung cancer, one on the brain cancer glioblastoma, and one on ovarian cancer. British Biotech expresses confidence that the drug will be more effective on earlier stages of cancer and says the small-cell lung cancer trials are expected to be the most promising. $\quad J G$

\section{USDA names biotech panel}

The US Department of Agriculture (USDA; Washington, DC) has announced the appointment of an advisory committee on agricultural biotechnology. Although some will see this as a response to growing concern over the regulation of biotech crops, the creation of the panel was approved two years ago. Members were selected by Agriculture Secretary Dan Glickman from a list generated by an internal committee, and the advisory committee will function to "offer advice to the Secretary of Agriculture on agricultural biotechnology issues," according to a USDA spokesman. The first meeting will take place March 29-30 in Washington, and its 38 members-including representatives from the biotechnology industry, academia, and organic farming-will establish procedural guidelines, select subcommittees, and determine an agenda for the group's two-year appointment. "It is my hope that this group, which brings together people with a wide range of perspectives and experiences, will engage in the kind of thoughtful and civil debate on biotechnology that our country now needs," says Glickman.

KS

\section{Athersys all the RAGE}

Athersys, a private biotech company based in Cleveland, $\mathrm{OH}$, has announced a joint venture with Elan Corp to develop and commercialize an undisclosed therapeutic protein for the treatment of AIDS-related muscle wasting. Although financial details were not disclosed, Elan has made a "significant equity investment" in Athersys. In return, Athersys is using its RAGE (Random Activation of Gene Expression) technology for the large-scale production of the therapeutic protein. According to Athersys, RAGE allows the activation and expression of protein from virtually every human gene-including those that are highly regulated and ordinarily silent - at its normal chromosomal location, without requiring the cloning of specific genes or cDNAs. Because RAGE activated protein expression does not require knowledge of the corresponding gene sequence, the technology could allow Athersys to circumvent intellectual property on cloned genes currently protecting already-established high-value protein therapeutics, such as insulin and erythropoietin.

Athersys has also filed US patents covering more than 10,000 novel gene sequences identified using RAGE, and has announced a functional genomics collaboration with Acorda Therapeutics (New York) to discover validated drug targets for use in treating nervous system disorders, such as multiple sclerosis. $\quad E D$ 